Fifth International Conference on Sustainable Construction Materials and

Technologies. http://www.claisse.info/Proceedings.htm

\title{
INNOVATIVE NANOPARTICLE-BASED ADMIXTURE FOR SUSTAINABLE CONSTRUCTION MATERIALS AND TECHNOLOGIES
}

\author{
Van Bui*), Chris Eagon, Steve Schaef and Paul Seiler \\ BASF Corporation, 23700 Chagrin Blvd., Beachwood, Ohio 44122, USA \\ *) Contact author's email:van.bui@basf.com
}

\begin{abstract}
Concrete plays a vital part in our daily lives. However, the production of concrete, notably cement, pose sustainability issues that need to be managed. To improve the sustainability of concrete, an innovative admixture, which contains Calcium Silicate Hydrate (C-S-H) particles, was recently developed at BASF Corporation. The patentpending admixture can significantly enhance concrete strength at both early and late ages. Compared with mortar mixes without the admixture, the mortar mixes containing the newly developed admixture and $65 \%$ slag, $30 \%$ fly ash or $35 \%$ milled limestone exhibited 1-day strength increase of $65 \%, 59 \%$ or $45 \%$, respectively. Similarly, compared with mortar mixes without the admixture the mortar mixes containing the newly developed admixture and $65 \%$ slag, $30 \%$ fly ash or $35 \%$ milled limestone exhibited 28 -day strength increase of $28 \%, 32 \%$ or $24 \%$, respectively. The use of this concrete admixture also enables a higher replacement of portland cement with supplementary materials such as fly ash, slag cement and milled limestone. In other hand, this innovative admixture can also enhance a reduction of considerable amount of cementitious materials, typically in range from $30 \mathrm{~kg} / \mathrm{m}^{3}$ to $60 \mathrm{~kg} / \mathrm{m}^{3}$. Thanks to the reduction of portland cement consumption in concrete, the use of this new admixture can contribute to reduce $\mathrm{CO}_{2}$-footprint. The information presented will show the use of nanoparticle-based liquid admixtures provides options to modify and improve fresh properties and strength of concrete.
\end{abstract}

Keywords: Admixture, Calcium-Silicate-Hydrate, Concrete, Nanoparticle, Strength, Strength-Enhancement, Supplementary Materials, Sustainability

\section{INTRODUCTION}

Nowadays sustainability in construction materials and technologies is of special attention in many countries around the world. Many R\&D efforts have been focusing on how to reduce $\mathrm{CO}_{2}$-footprint, material usage and energy consumption in construction industry. Concrete plays a vital part in our daily lives, however, the 
production of concrete, notably cement, pose sustainability issues that need to be managed (Hanle et al.; Rubenstein, 2012). To improve the sustainability of concrete, scientists are turning toward nanotechnology solutions (Bjornstrom et al., 2009, Collepardi et al., 2002, Li, 2004, Porro et al., 2005, Scrivener, 2009 and Sobolev et al, 2012). One of the nanotechnology solutions is development of an admixture containing Calcium Silicate Hydrate $(\mathrm{C}-\mathrm{S}-\mathrm{H})$ particles which improve the cement hydration process and provide a way to reduce the cementitious material content. This brings a significant contribution to the sustainability in construction by limiting the use of natural resources, conserving energy and reducing $\mathrm{CO}_{2}$-emissions. An innovative $\mathrm{C}$ $\mathrm{S}-\mathrm{H}$ nanoparticle-containing admixture (the Master X-Seed 55 admixture, hereafter called NPA) was recently developed at BASF Corporation (see reference in BASF document). The patent-pending admixture can significantly enhance concrete strength at both early and late ages. The use of this concrete admixture enables a higher replacement of portland cement with supplementary materials such as fly ash, slag cement and milled limestone. In other hand, this innovative admixture can also enhance a reduction of considerable amount of cementitious materials. Thanks to the reduction of portland cement consumption in concrete, the use of this new admixture also contributes to reduce $\mathrm{CO}_{2}$-footprint. The use of the admixture can also contribute to reduce energy needed in concrete curing and enhance earlier transportation of cast elements as well as increase of construction speed.

The information presented will show the use of nanoparticle-based liquid admixtures provides options to modify and improve the fresh properties and strength of concrete. This paper will present test results evaluated with mortar and concrete mixtures.

\section{TEST RESULTS AND DISCUSSIONS}

\section{NPA's Strength-Enhancement for Mixes with High Supplementary Materials Contents}

Mortars containing Portland cement and different contents of Class F fly ash $(30 \%$, $40 \%$ and $50 \%$ replacement), slag cement (65\% replacement) or milled limestone (35\% replacement) were evaluated. The evaluation program has been presented in detail in other publication (Seiler et al, 2017). Mortars had water-to-cementitious materials ratio $(\mathrm{w} / \mathrm{cm})$ of 0.51 and 0.40 . Batch compositions of mortars and test results are shown in Table 1 and 2. The strength test results can be also seen in Fig. 1 and 2.

Table 1: Fly Ash Containing Mortars and Test Results

\begin{tabular}{|l|c|c|c|c|c|c|}
\hline Mix ID & $\begin{array}{c}\text { FA30, } \\
\text { No-NPA }\end{array}$ & $\begin{array}{c}\text { FA30, } \\
\text { NPA }\end{array}$ & $\begin{array}{c}\text { FA40, } \\
\text { No-NPA }\end{array}$ & $\begin{array}{c}\text { FA40, } \\
\text { NPA }\end{array}$ & $\begin{array}{c}\text { FA50, } \\
\text { No-NPA }\end{array}$ & $\begin{array}{c}\text { FA50, } \\
\text { NPA }\end{array}$ \\
\hline Cement (g) & 1029 & 1029 & 882 & 882 & 770 & 770 \\
\hline Fly ash $(\mathrm{g})$ & 411 & 411 & 588 & 588 & 770 & 770 \\
\hline Sand $(\mathrm{g})$ & 2500 & 2500 & 2500 & 2500 & 2500 & 2500 \\
\hline w/cm & 0.51 & 0.51 & 0.51 & 0.51 & 0.40 & 0.40 \\
\hline
\end{tabular}




\begin{tabular}{|l|c|c|c|c|c|c|}
\hline $\begin{array}{l}\text { NPA } \\
(\mathrm{mL} / 100 \mathrm{~kg})\end{array}$ & 1150 & & 1150 & & 820 \\
\hline Flow (mm) & 188 & 204 & 190 & 206 & 112 & 110 \\
\hline \multicolumn{6}{|l}{ Compressive strength (MPa) } \\
\hline 1 day & 6.76 & 10.76 & 5.79 & 8.97 & 7.59 & 10.41 \\
\hline 7 days & 21.17 & 32.28 & 18.76 & 25.66 & 17.38 & 23.24 \\
\hline 28 days & 34.97 & 46.07 & 31.10 & 38.48 & 27.72 & 37.03 \\
\hline
\end{tabular}

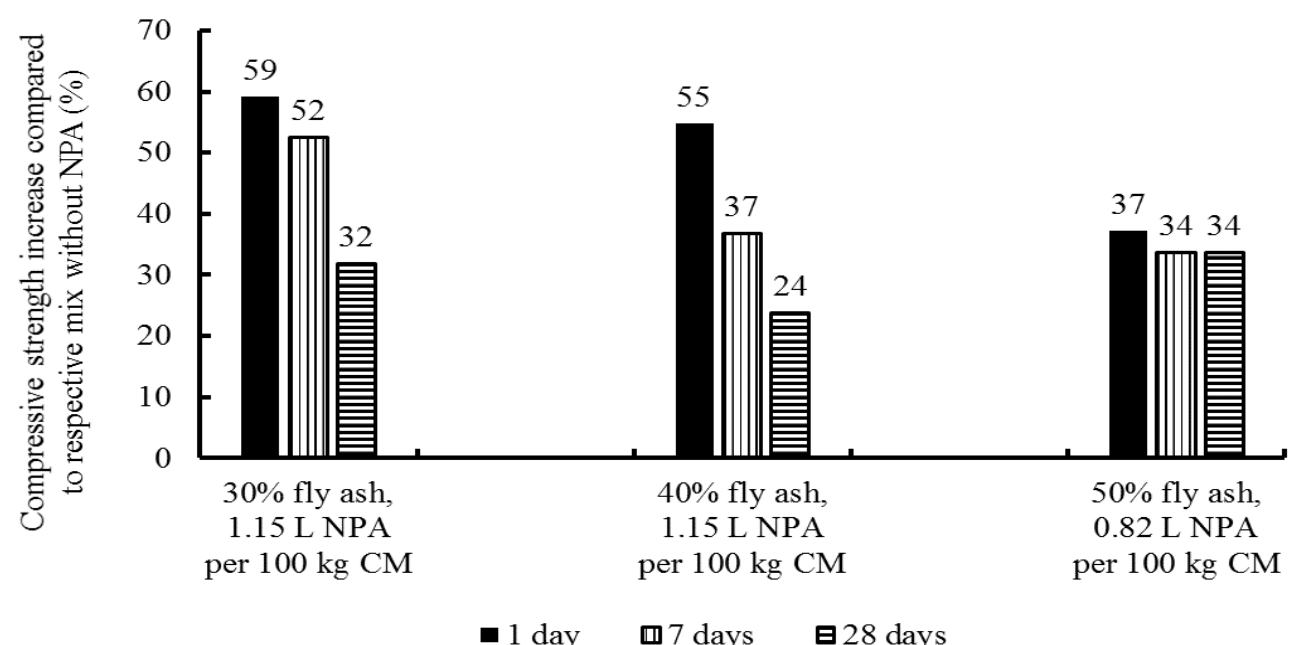

Fig. 1: Compressive strength increase of fly ash containing mortars with NPA admixture in comparison with respective no-NPA mortars

As can be seen in Table 1 and Fig. 1, for the same w/cm of 0.51 and $30 \%$ fly ash replacement, mortar with NPA exhibited strength at age of 1 day, 7 days and 28 days, being $59 \%, 52 \%$ and $32 \%$, respectively, higher than that of respective mortar without NPA. Similarly, for the same w/cm of 0.51 and $40 \%$ fly ash replacement, mortar with NPA exhibited strength at age of 1 day, 7 days and 28 days, being 55\%, 37\% and 24\%, respectively, higher than that of respective mortar without NPA. For the same w/cm and the same dosage of NPA, NPA-mix with lower fly ash replacement (30\%) had higher respective percentage increase of strength at all ages than NPA-mix with higher fly ash replacement (40\%). This suggests that NPA influences more on the hydration process of Portland cement.

Fig. 1 also shows that, for the same w/cm of 0.40 and $50 \%$ fly ash replacement, mortar with NPA exhibited strength at age of 1 day, 7 days and 28 days, being 37\%, 34\% and $34 \%$, respectively, higher than that of respective mortar without NPA.

Table 2: Slag Cement/Milled Limestone Containing Mortars and Test Results

\begin{tabular}{|l|c|c|c|c|}
\hline Mix ID & SL65, ref. & SL65, NPA & LS35, ref. & LS35, NPA \\
\hline Cement (g) & 539 & 539 & 1001 & 1001 \\
\hline Ground slag (g) & 1001 & 1001 & & \\
\hline
\end{tabular}




\begin{tabular}{|l|c|c|c|c|}
\hline $\begin{array}{l}\text { Milled limestone } \\
(\mathrm{g})\end{array}$ & & & 539 & 539 \\
\hline Sand $(\mathrm{g})$ & 2500 & 2500 & 2500 & 2500 \\
\hline w/cm & 0.45 & 0.45 & 0.40 & 0.40 \\
\hline NPA (mL/100 kg) & \multicolumn{1}{l|}{} & 1920 \\
\hline Flow (mm) & 107 & 1920 & 105 & 115 \\
\hline \multicolumn{4}{l|}{ Compressive strength (MPa) at age: } \\
\hline \multicolumn{1}{|l|}{ 1 day } & 6.62 & 10.90 & 15.52 & 22.55 \\
\hline 7 days & 33.33 & 53.63 & 31.29 & 40.88 \\
\hline 28 days & 55.10 & 70.48 & 40.34 & 50.00 \\
\hline
\end{tabular}

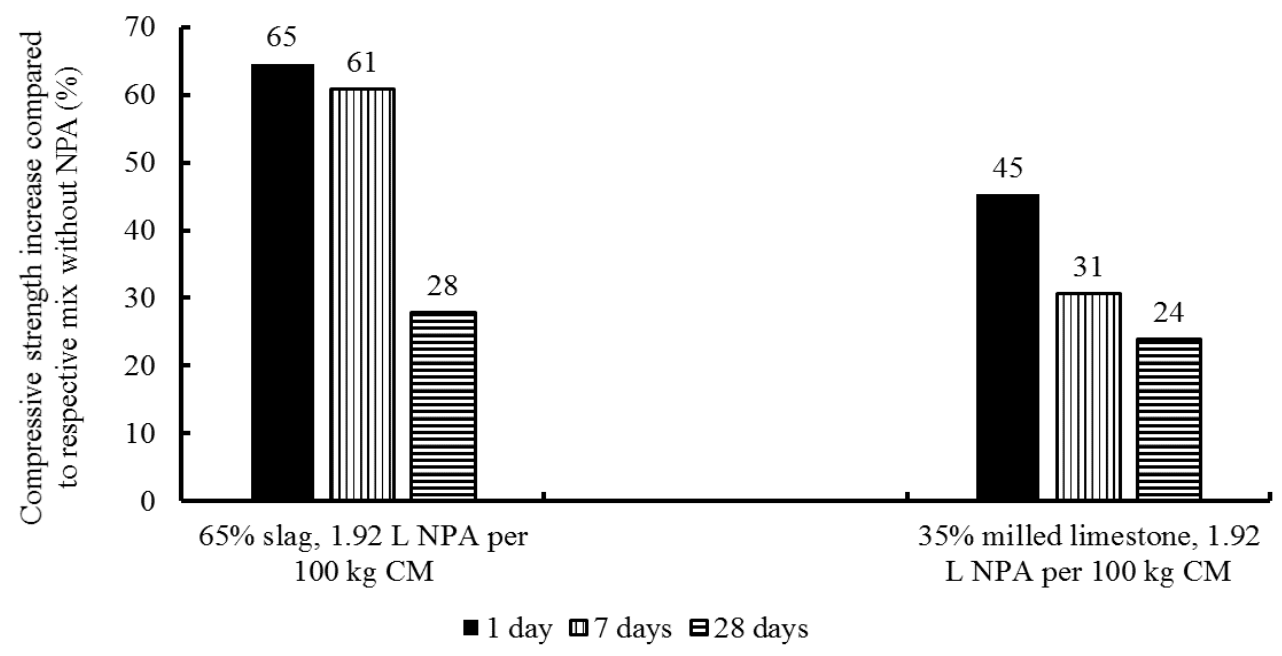

Fig. 2: Compressive strength increase of slag/milled limestone containing mortars with NPA admixture in comparison with respective no-NPA mortars

As can be seen from Table 2 and Fig. 2, for the same w/cm of 0.45 and $65 \%$ slag replacement, mortar with NPA exhibited strength at age of 1 day, 7 days and 28 days, being $65 \%, 61 \%$ and $28 \%$, respectively, higher than that of respective mortar without NPA. Similarly, for the same w/cm of 0.40 and $35 \%$ milled-limestone replacement, mortar with NPA exhibited strength at age of 1 day, 7 days and 28 days, being 45\%, $31 \%$ and $24 \%$, respectively, higher than that of respective mortar without NPA.

\section{NPA's Strength Enhancement for Wide Ranges of Concrete Mixtures}

Examples of using NPA in non-air-entrained concrete mixtures with different ratios $(w / \mathrm{cm})$ between water and total cementitious materials and different supplementary materials (SM) can be seen in Tables 3, and from Fig. 3 to Fig. 5. Compressive strengths of non-air-entrained concrete mixtures with different water to cement ratios (w/c) and Portland cement only are illustrated in Fig. 6 and 7. Fig. 8 shows the strength development of air-entrained concrete mixtures without and with NPA. 
Table 3: Proportions and Test Results of Concrete with Different w/cm Ratios

\begin{tabular}{|c|c|c|c|c|c|c|}
\hline Mix ID & $\begin{array}{c}0.53 \mathrm{w} / \mathrm{c} \\
\mathrm{m}, \mathrm{No}- \\
\mathrm{NPA}\end{array}$ & $\begin{array}{l}0.53 \mathrm{w} / \mathrm{c} \\
\mathrm{m}, \mathrm{NPA}\end{array}$ & $\begin{array}{c}0.45 \mathrm{w} / \mathrm{c} \\
\mathrm{m}, \mathrm{No}- \\
\mathrm{NPA}\end{array}$ & $\begin{array}{l}0.45 \mathrm{w} / \mathrm{c} \\
\mathrm{m}, \mathrm{NPA}\end{array}$ & $\begin{array}{c}0.29 \mathrm{w} / \mathrm{c} \\
\mathrm{m}, \mathrm{No}- \\
\mathrm{NPA}\end{array}$ & $\begin{array}{l}0.29 \mathrm{w} / \mathrm{c} \\
\mathrm{m}, \mathrm{NPA}\end{array}$ \\
\hline \multicolumn{7}{|c|}{ Concrete materials $(\mathrm{kg} / \mathrm{m} 3)$} \\
\hline Cement & 268 & 268 & 290 & 290 & 237 & 237 \\
\hline Fly ash & 67 & 67 & 73 & 73 & & \\
\hline Ground Slag & & & & & 356 & 356 \\
\hline Silica fume & & & & & 12 & 12 \\
\hline $\begin{array}{c}\text { Coarse } \\
\text { aggregate }\end{array}$ & 1122 & 1122 & 1122 & 1122 & 949 & 949 \\
\hline Sand & 740 & 740 & 752 & 752 & 653 & 653 \\
\hline Water & 177 & 177 & 163 & 163 & 176 & 176 \\
\hline $\mathrm{w} / \mathrm{cm}$ & 0.530 & 0.530 & 0.450 & 0.450 & 0.290 & 0.290 \\
\hline Design air (\%) & 2.5 & 2.5 & 2.5 & 2.5 & 2.0 & 2.0 \\
\hline \multicolumn{7}{|c|}{ Chemical admixtures (mL/100 kg cementitious materials) } \\
\hline $\begin{array}{l}\text { Superplasticize } \\
\mathrm{r}\end{array}$ & 0 & 0 & 196 & 163 & 635 & 596 \\
\hline NPA & 0 & 980 & 0 & 980 & 0 & 490 \\
\hline
\end{tabular}

Table 3: Proportions and Test Results of Concrete with Different w/cm Ratios (cont'd)

\begin{tabular}{|c|c|c|c|c|c|c|}
\hline Mix ID & $\begin{array}{c}0.53 \mathrm{w} / \mathrm{c} \\
\mathrm{m}, \mathrm{No}- \\
\mathrm{NPA}\end{array}$ & $\begin{array}{l}0.53 \mathrm{w} / \mathrm{c} \\
\mathrm{m}, \mathrm{NPA}\end{array}$ & $\begin{array}{c}0.45 \mathrm{w} / \mathrm{c} \\
\mathrm{m}, \mathrm{No}- \\
\mathrm{NPA}\end{array}$ & $\begin{array}{l}0.45 \mathrm{w} / \mathrm{c} \\
\mathrm{m}, \mathrm{NPA}\end{array}$ & $\begin{array}{c}0.29 \mathrm{w} / \mathrm{c} \\
\mathrm{m}, \mathrm{No}- \\
\mathrm{NPA}\end{array}$ & $\begin{array}{l}0.29 \mathrm{w} / \mathrm{c} \\
\mathrm{m}, \mathrm{NPA}\end{array}$ \\
\hline Slump (mm) & 171 & 165 & 171 & 178 & & \\
\hline $\begin{array}{l}\text { Slump flow } \\
\text { (mm) }\end{array}$ & & & & & 616 & 641 \\
\hline Air $(\%)$ & 2.9 & 2.6 & 2.7 & 3.1 & 2.0 & 2.1 \\
\hline \multicolumn{7}{|c|}{ Compressive strength (MPa) at: } \\
\hline 1 day & 12.28 & 15.24 & 19.31 & 21.79 & 25.86 & 28.14 \\
\hline 7 days & 24.28 & 30.14 & 31.59 & 38.97 & 74.48 & 72.07 \\
\hline 28 days & 33.59 & 40.34 & 41.52 & 50.69 & 93.17 & 99.79 \\
\hline 56 days & No-test & No-test & No-test & No-test & 96.55 & 103.66 \\
\hline
\end{tabular}




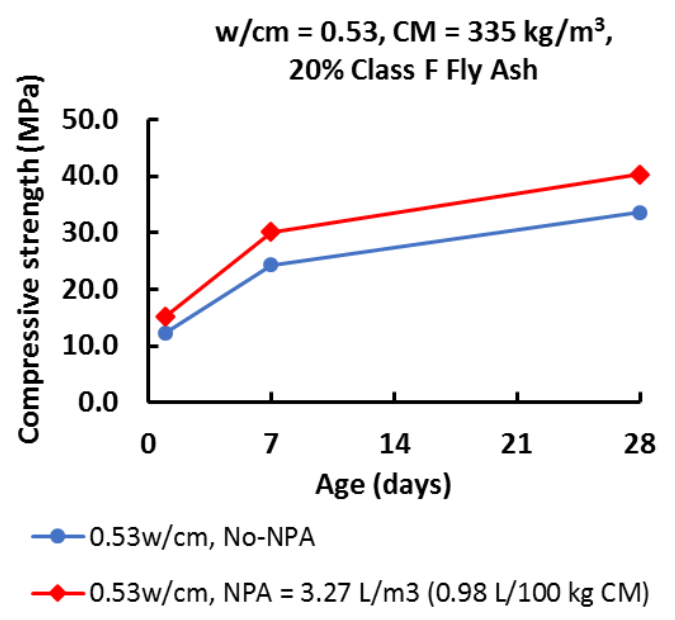

Fig. 3: Concrete with w/cm of 0.53 and $20 \%$ fly ash

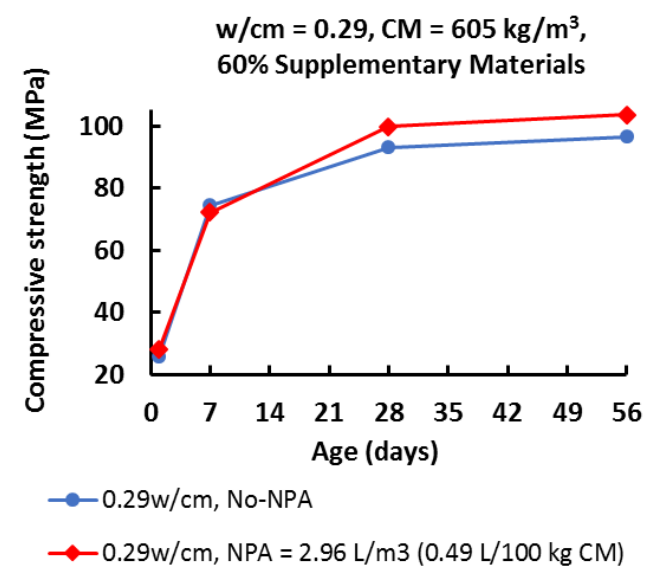

Fig. 5: Concrete with w/cm of 0.29 and $60 \%$ supplementary materials

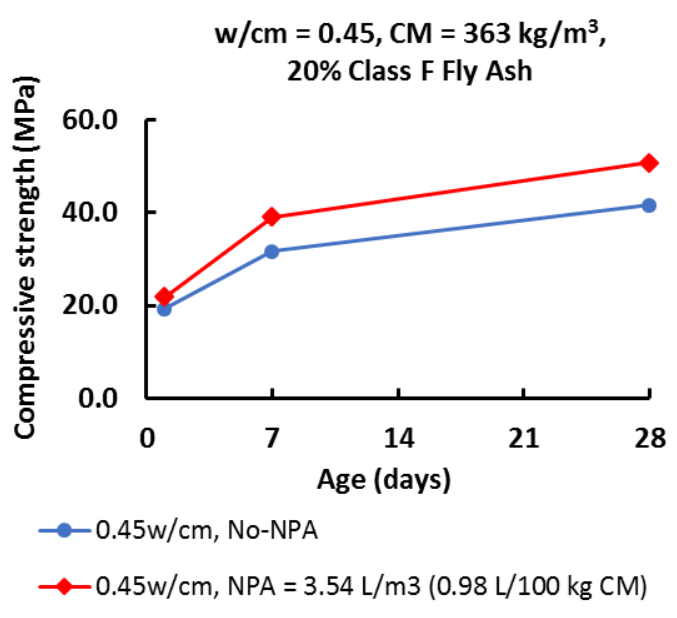

Fig. 4: Concrete with w/cm of 0.45 and $20 \%$ fly ash

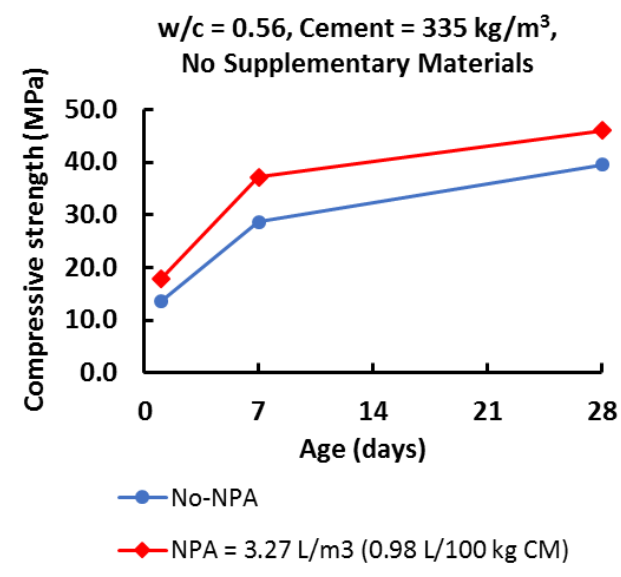

Fig. 6: Concrete with w/c of 0.56 and Portland cement only 


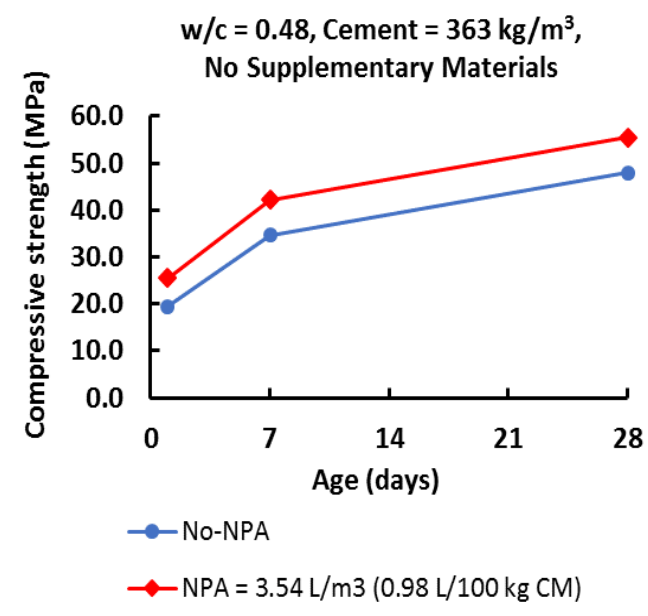

Fig. 7: Concrete with w/c of 0.48 and Portland cement only

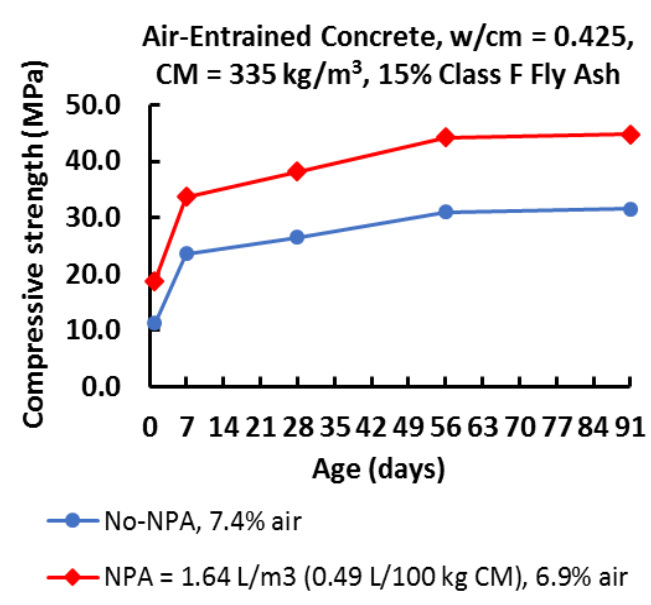

Fig. 8: Air-entrained concrete without and with NPA

As can be seen in Table 3 and from Fig. 3 to Fig. 7, NPA increases considerably strength at early and late ages for the wide ranges of non-air-entrained concrete mixtures with different w/cm (i.e. $0.56,0.53,0.48,0.45$ and 0.29 ) and different contents of supplementary materials (i.e. $0 \%, 20 \%$ and $60 \%$ ). Fig. 8 shows significant strength enhancement of NPA for air-entrained concrete mixture. The conclusion is that NPA can be used to increase strength of concrete mixtures for a wide construction application.

\section{Use of NPA for Reduction of Cementitious Materials in Concrete Mixtures}

The compositions and test results of concrete mixtures with reduced cementitious materials are shown in Table 4, 5 and 6, and from Fig. 9 to Fig. 11, inclusively.

As can be seen in Table 4 and Fig. 9, for use of Portland cement only, mixtures with NPA and cement reduction of $30 \mathrm{~kg} / \mathrm{m}^{3}, 45 \mathrm{~kg} / \mathrm{m}^{3}$ and $60 \mathrm{~kg} / \mathrm{m}^{3}$ and higher w/c $(0.58$, 0.59 and 0.60 ) exhibited similar or greater strength at ages of 1 day, 7 days and 28 days in comparison with non-NPA mixture with higher cement content and lower w/c (0.56).

Similarly, for use of $15 \%$ ground slag, mixtures with NPA and cementitious material reduction of $30 \mathrm{~kg} / \mathrm{m}^{3}, 45 \mathrm{~kg} / \mathrm{m}^{3}$ and $60 \mathrm{~kg} / \mathrm{m}^{3}$ and higher $\mathrm{w} / \mathrm{cm}(0.364,0.372$ and 0.382) exhibited similar or greater strength at ages from 1 day, 7 days, 28 days, 56 days and 90 days in comparison with non-NPA mixtures with higher cementitious material content and lower w/cm (0.351) (see Table 5 and Fig. 10).

For the use of $15 \%$ fly ash, mixtures with NPA and cementitious material reduction of $48 \mathrm{~kg} / \mathrm{m}^{3}$ and $52 \mathrm{~kg} / \mathrm{m}^{3}$ and higher w/cm (0.595 and 0.61) exhibited similar or greater strength at ages of 1 day, 7 days and 28 days in comparison with non-NPA mixtures with higher cementitious material content and lower w/cm (0.56) (see Table 6 and Fig. 11). The cementitious material reduction, thanks to use of NPA, contributes to reduce $\mathrm{CO}_{2}$-foot print, as production of cement generates high $\mathrm{CO}_{2}$-emissions into environment. 
Table 4: Composition and Test Results of Mixtures with NPA and Cement Reduction

\begin{tabular}{|c|c|c|c|c|}
\hline Mix ID & O-CR, ref. & 30-CR, NPA & 45-CR, NPA & 60-CR, NPA \\
\hline \multicolumn{5}{|c|}{ Concrete materials $\left(\mathrm{kg} / \mathrm{m}^{3}\right)$} \\
\hline Cement & 335 & 305 & 290 & 275 \\
\hline CM reduction* & 0 & 30 & 45 & 60 \\
\hline Coarse aggregate & 1122 & 1135 & 1135 & 1135 \\
\hline Sand & 734 & 772 & 799 & 826 \\
\hline $\mathrm{w} / \mathrm{cm}$ & 0.56 & 0.58 & 0.59 & 0.60 \\
\hline Design air $(\%)$ & 2.5 & 2.5 & 2.5 & 2.5 \\
\hline $\operatorname{NPA}\left(\mathrm{L} / \mathrm{m}^{3}\right)$ & 0 & 0.96 & 1.37 & 1.73 \\
\hline Slump (mm) & 191 & 178 & 178 & 171 \\
\hline Measured air (\%) & 1.9 & 2.0 & 2.0 & 2.0 \\
\hline \multicolumn{5}{|c|}{ Compressive strength (MPa) } \\
\hline 1 day & 12.48 & 14.83 & 14.48 & 14.41 \\
\hline 7 days & 27.10 & 30.41 & 32.07 & 32.07 \\
\hline 28 days & 37.17 & 43.38 & 42.14 & 45.17 \\
\hline
\end{tabular}

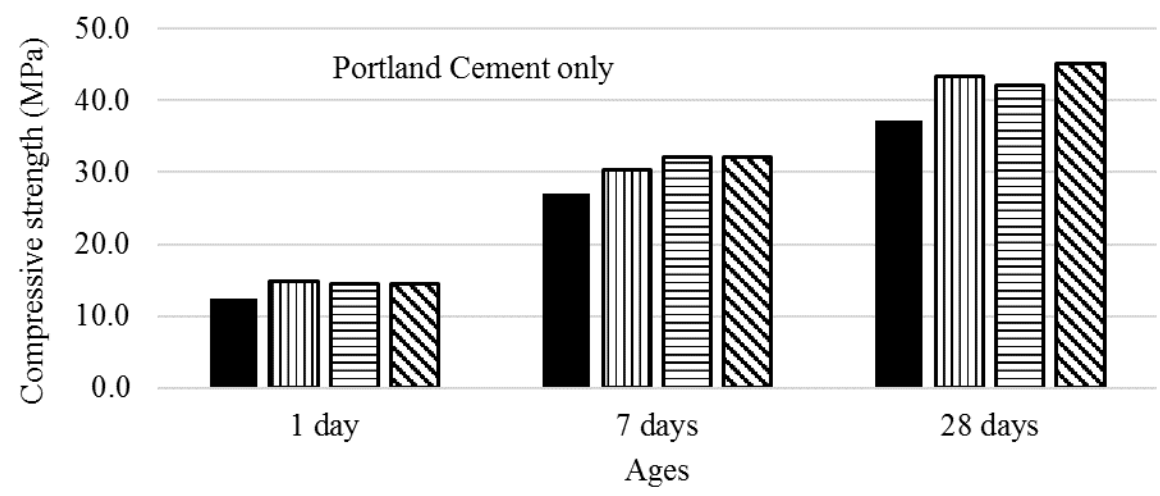

-No-NPA, $\mathrm{w} / \mathrm{c}=0.56$, Cement $=335 \mathrm{~kg} / \mathrm{m} 3$

$\boldsymbol{\square} \mathrm{NPA}=0.96 \mathrm{~L} / \mathrm{m} 3, \mathrm{w} / \mathrm{c}=0.58$, Cement $=305 \mathrm{~kg} / \mathrm{m} 3$ (cement reduction $=30 \mathrm{~kg} / \mathrm{m} 3$ )

日NPA $=1.37 \mathrm{~L} / \mathrm{m} 3, w / \mathrm{c}=0.59$, Cement $=290 \mathrm{~kg} / \mathrm{m} 3($ cement reduction $=45 \mathrm{~kg} / \mathrm{m} 3)$

$\mathbf{Q N P A}=1.73 \mathrm{~L} / \mathrm{m} 3, \mathrm{w} / \mathrm{c}=0.60$, Cement $=275 \mathrm{~kg} / \mathrm{m} 3($ cement reduction $=60 \mathrm{~kg} / \mathrm{m} 3)$

Fig. 9: Compressive strength of NPA-containing concrete with different amounts of Portland cement reduction compared with that of concrete without NPA

Table 5: Composition and Test Results of NPA-Mixtures and CM Reduction

\begin{tabular}{|l|c|c|c|c|}
\hline Mix ID & O-CR, ref. & 30-CR, NPA & 45-CR, NPA & 60-CR, NPA \\
\hline Concrete materials $\left(\mathrm{kg} / \mathrm{m}^{3}\right)$ & \multicolumn{5}{|l|}{} \\
\hline Cement & 393 & 367 & 354 & 342 \\
\hline Ground slag & 69 & 65 & 63 & 60 \\
\hline CM reduction* & 0 & 30 & 45 & 60 \\
\hline Coarse aggregate & 1127 & 1139 & 1154 & 1154 \\
\hline Sand & 718 & 709 & 724 & 742 \\
\hline
\end{tabular}




\begin{tabular}{|c|c|c|c|c|}
\hline $\mathrm{w} / \mathrm{cm}$ & 0.351 & 0.364 & 0.373 & 0.382 \\
\hline \multicolumn{5}{|c|}{ Table 5: Composition and Test Results of NPA-Mixtures with CM Reduction (cont'd) } \\
\hline Mix ID & O-CR, ref. & 30-CR, NPA & 45-CR, NPA & 60-CR, NPA \\
\hline Design air $(\%)$ & 2.5 & 2.5 & 2.5 & 2.5 \\
\hline $\operatorname{NPA}\left(\mathrm{L} / \mathrm{m}^{3}\right)$ & 0 & 1.37 & 1.97 & 2.53 \\
\hline $\begin{array}{l}\text { Superplasticizer } \\
(\mathrm{mL} / 100 \mathrm{~kg} \mathrm{CM})\end{array}$ & 254 & 287 & 280 & 287 \\
\hline $\begin{array}{l}\mathrm{WRA}^{* *}(\mathrm{~mL} / 100 \mathrm{~kg} \\
\mathrm{CM})\end{array}$ & 261 & 196 & 196 & 209 \\
\hline Slump (mm) & 210 & 203 & 210 & 210 \\
\hline Measured air (\%) & 2.9 & 2.7 & 2.4 & 2.4 \\
\hline \multicolumn{5}{|c|}{ Compressive strength (MPa) } \\
\hline 1 day & 21.66 & 23.59 & 26.76 & 21.52 \\
\hline 7 days & 51.93 & 55.93 & 55.45 & 56.34 \\
\hline 28 days & 68.07 & 69.38 & 68.83 & 66.07 \\
\hline 56 days & 70.55 & 72.00 & 71.59 & 73.59 \\
\hline 90 days & 71.66 & 75.24 & 76.76 & 78.83 \\
\hline \multicolumn{5}{|c|}{$\begin{array}{l}\text { Note: } * \text { Cementitious materials }(C M) \text { reduction compared with reference mix (Mix } \\
\text { O-CR, ref.) } \\
\quad * * W R A \text { is water-reducing admixture }\end{array}$} \\
\hline
\end{tabular}

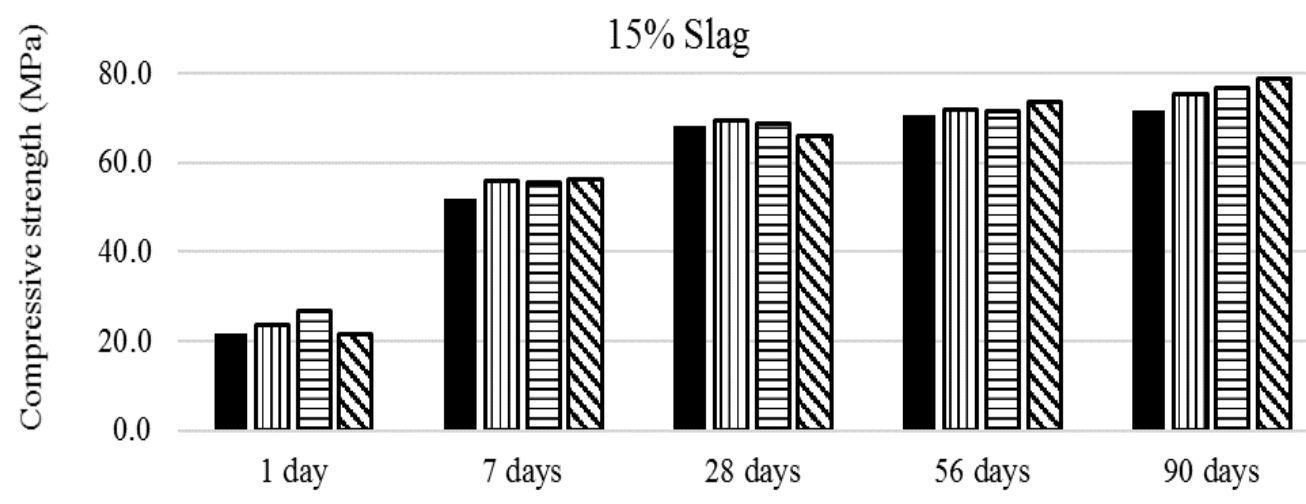

- No-NPA, $\mathrm{w} / \mathrm{cm}=0.351, \mathrm{CM}=462 \mathrm{~kg} / \mathrm{m} 3$

$\mathbb{D N P A}=1.37 \mathrm{~L} / \mathrm{m} 3, \mathrm{w} / \mathrm{cm}=0.364, \mathrm{CM}=432 \mathrm{~kg} / \mathrm{m} 3$ (cementitious materials reduction $=30 \mathrm{~kg} / \mathrm{m} 3$ ) 日NPA $=1.97 \mathrm{~L} / \mathrm{m} 3, \mathrm{w} / \mathrm{cm}=0.373, \mathrm{CM}=417 \mathrm{~kg} / \mathrm{m} 3$ (cementitious materials reduction $=45 \mathrm{~kg} / \mathrm{m} 3$ ) $\mathbf{\nabla N P A}=2.53 \mathrm{~L} / \mathrm{m} 3, \mathrm{w} / \mathrm{cm}=0.382, \mathrm{CM}=402 \mathrm{~kg} / \mathrm{m} 3$ (cementitious materials reduction $=60 \mathrm{~kg} / \mathrm{m} 3$ )

Fig. 10: Compressive strength of NPA-containing concrete with different amounts of cementitious material reduction compared with that of concrete without NPA

Table 6: Composition and Test Results of NPA-Mixtures and CM Reduction

\begin{tabular}{|l|c|c|c|}
\hline Mix ID & O-CR, ref. & 48-CR, NPA & 52-CR, NPA \\
\hline Cement $\left(\mathrm{kg} / \mathrm{m}^{3}\right)$ & 261 & 220 & 217 \\
\hline
\end{tabular}




\begin{tabular}{|l|c|c|c|}
\hline Fly ash $\left(\mathrm{kg} / \mathrm{m}^{3}\right)$ & 46 & 39 & 38 \\
\hline CM reduction* $\left(\mathrm{kg} / \mathrm{m}^{3}\right)$ & 0 & 48 & 52 \\
\hline
\end{tabular}

Table 6: Composition and Test Results of NPA-Mixtures and CM Reduction (cont'd)

\begin{tabular}{|c|c|c|c|}
\hline Mix ID & $\mathrm{O}-\mathrm{CR}$, ref. & 48-CR, NPA & 52-CR, NPA \\
\hline Coarse aggregate $\left(\mathrm{kg} / \mathrm{m}^{3}\right)$ & 1122 & 1135 & 1135 \\
\hline Sand $\left(\mathrm{kg} / \mathrm{m}^{3}\right)$ & 785 & 860 & 857 \\
\hline $\mathrm{w} / \mathrm{cm}$ & 0.560 & 0.595 & 0.610 \\
\hline Design air (\%) & 2.5 & 2.5 & 2.5 \\
\hline $\operatorname{NPA}\left(\mathrm{L} / \mathrm{m}^{3}\right)$ & 0 & 1.42 & 1.99 \\
\hline Slump (mm) & 216 & 146 & 184 \\
\hline Measured air $(\%)$ & 2.3 & 2.3 & 2.2 \\
\hline \multicolumn{4}{|c|}{ Compressive strength (MPa) } \\
\hline 1 day & 10.97 & 12.21 & 13.59 \\
\hline 7 days & 23.45 & 27.10 & 24.07 \\
\hline 28 days & 31.72 & 36.00 & 34.55 \\
\hline
\end{tabular}

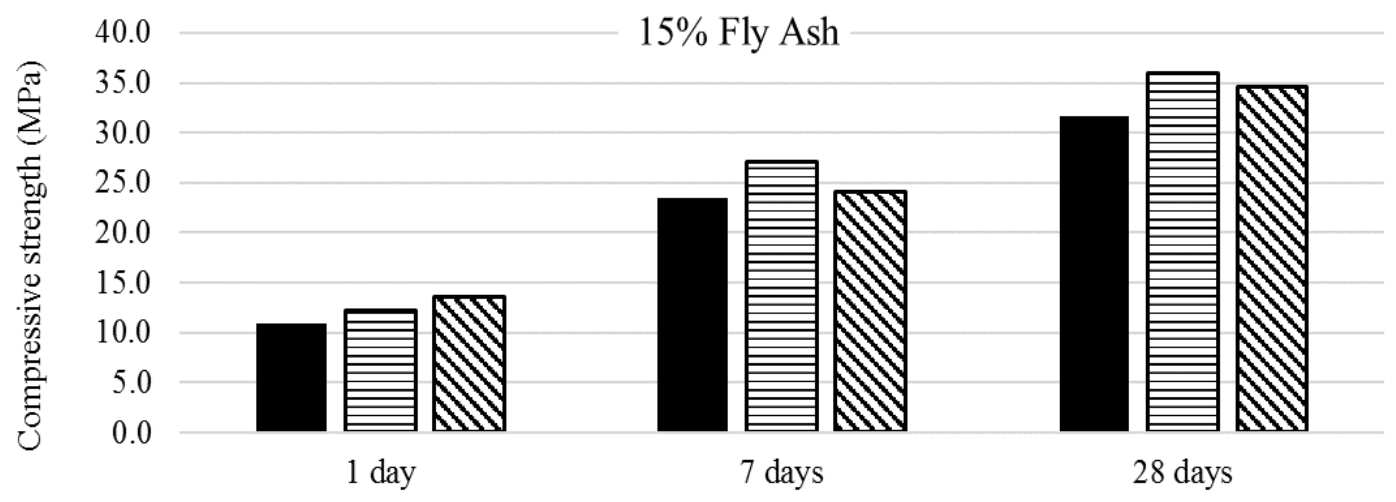

- No-NPA, $\mathrm{w} / \mathrm{cm}=0.560, \mathrm{CM}=307 \mathrm{~kg} / \mathrm{m} 3$

घNPA $=1.42 \mathrm{~L} / \mathrm{m} 3, \mathrm{w} / \mathrm{cm}=0.595, \mathrm{CM}=259 \mathrm{~kg} / \mathrm{m} 3$ (cementitious materials reduction $=48 \mathrm{~kg} / \mathrm{m} 3$ )

$\mathbf{D N P A}=1.99 \mathrm{~L} / \mathrm{m} 3, \mathrm{w} / \mathrm{c}=0.610, \mathrm{CM}=429 \mathrm{~kg} / \mathrm{m} 3$ (cementitious materials reduction $=52 \mathrm{~kg} / \mathrm{m} 3$ )

Fig. 11: Compressive strength of NPA-containing concrete with different amounts of cementitious material reduction compared with that of concrete without NPA

\section{NPA Enhancement of Early-Age Strength of Concrete Mixtures}

NPA was used in evaluating its enhancement of early-age strength of concrete mixtures, which are typically used in precast/prestressed concrete application. Cement content of $445 \mathrm{~kg} / \mathrm{m}^{3}$ and $337 \mathrm{~kg} / \mathrm{m}^{3}$ and w/c of 0.371 and 0.398 , respectively were used in concrete mixtures without and with NPA (see Table 7). Test results in Table 7 and Fig. 12 show that, for the same w/c and the same cement content, concrete with NPA exhibited significantly higher 16-h strengths than those of concrete without NPA. This implies that use of NPA can reduce a time of curing or heat curing for precast/prestressed concrete elements. The test results also show that NPA-concrete with lower cement content $\left(337 \mathrm{~kg} / \mathrm{m}^{3}\right)$ had higher $16-\mathrm{h}$ strength $(29.2 \mathrm{MPa})$ than that 
(26.9 MPa) of non-NPA concrete with higher cement content $\left(445 \mathrm{~kg} / \mathrm{m}^{3}\right)$. One can conclude that the use of NPA enhances the sustainability thanks to the reduction of cement consumption and energy needed for heat-curing in manufacturing precast/prestressed concrete elements.

Table 7: Composition and Early-Age Strength of NPA-Containing Concrete

\begin{tabular}{|l|c|c|c|c|}
\hline Mix ID & $\begin{array}{c}\text { 445C, } \\
\text { No-NPA }\end{array}$ & $\begin{array}{c}445 \mathrm{C}, \\
\text { NPA }\end{array}$ & $\begin{array}{c}337 \mathrm{C}, \\
\text { No-NPA }\end{array}$ & $\begin{array}{c}337 \mathrm{C}, \\
\text { NPA }\end{array}$ \\
\hline Cement $\left(\mathrm{kg} / \mathrm{m}^{3}\right)$ & 445 & 445 & 377 & 377 \\
\hline Coarse aggregate $\left(\mathrm{kg} / \mathrm{m}^{3}\right)$ & 1071 & 1071 & 1129 & 1129 \\
\hline Natural Sand $\left(\mathrm{kg} / \mathrm{m}^{3}\right)$ & 682 & 682 & 719 & 719 \\
\hline Water $\left(\mathrm{kg} / \mathrm{m}^{3}\right)$ & 165 & 165 & 150 & 150 \\
\hline w/c & 0.371 & 0.371 & 0.398 & 0.398 \\
\hline Design air $(\%)$ & 2.0 & 2.0 & 2.0 & 2.0 \\
\hline $\begin{array}{l}\text { Superplasticizer }(\mathrm{mL} / 100 \mathrm{~kg} \\
\text { CM) }\end{array}$ & 522 & 522 & 522 & 522 \\
\hline NPA (mL/100 kg CM) & 0 & 652 & 0 & 652 \\
\hline Slump (mm) & 203 & 203 & 203 & 203 \\
\hline Measured air $(\%)$ & 1.5 & 2.0 & 1.6 & 2.1 \\
\hline $\begin{array}{l}\text { 16-h compressive strength } \\
\text { (MPa) }\end{array}$ & 26.9 & 35.7 & 23.4 & 29.2 \\
\hline
\end{tabular}

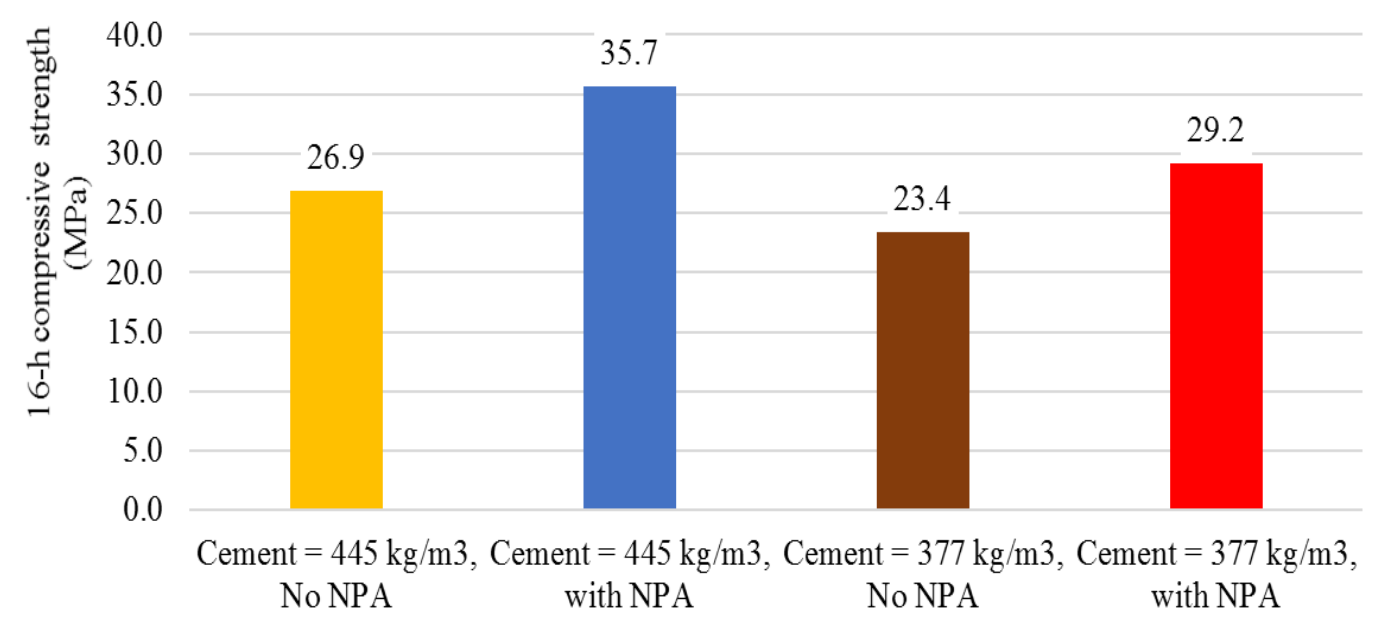

Fig. 12: Early-age compressive strength of NPA-containing concrete with different cement contents

\section{SUMMARY}

The newly-developed nanoparticle-containing admixture (NPA) significantly increases concrete strength at both early and late ages. It can enhance a replacement of high Portland cement content with supplementary materials in concrete mixtures. The use of the nanoparticle-containing admixture can also reduce considerably the cementitious 
material consumption and/or energy needed for heat-curing of concrete elements. Thanks to high early-age strength of NPA concrete, the cast elements can be shipped earlier to construction site and lead to increase of construction speed. Thus, use of the innovative nanoparticle-containing admixture can contribute to reduce $\mathrm{CO}_{2}$-foot print and enhance sustainability in concrete production and construction technologies.

\section{REFERENCES}

BASF document "Master X-Seed 55 - Strength Enhancing Admixture" https://www.master-builders-solutions.basf.us/en-us/products/concreteadmixtures/increasing-concrete-strength/master-X-seed-55.

Bjornstrom, J., Martinelli, A., Matic, A., Borjesson, L., Panas, I. (2004) “Accelerating Effects of Colloidal Nano-Silica for Beneficial Calcium-Silicate-Hydrate Formation in Cement", Chem Phys Lett, 2004;392(1-3): pp. 242-248.

Collepardi, M., Ogoumah-Olagot, J.J., Skarp, U., Troli, R., (2002) "Influence of Amorphous Colloidal Silica on the Properties of Self-Compacting Concretes", Proceedings of the International Conference on Challenges in Concrete Construction - Innovations and Developments in Concrete Materials and Construction, Dundee, UK, 2002, pp. 473 - 483.

Hanle, L. J., Jayaraman, K. R., and Smith J. S. " $\mathrm{CO}_{2}$ Emissions Profile of the U.S. Cement Industry", https://www3.epa.gov/ttnchie1/conference/ei13/ghg/hanle.pdf

Li, G. (2004) "Properties of High-Volume Fly Ash Concrete Incorporating Nano$\mathrm{SiO}_{2}$ ", Cement and Concrete Research Journal, 34, 2004, pp.1043-1049.

Porro, A., Dolado, J.S., Campillo, I., Erkizia, E., de Miguel, Y., Sáez de Ibarra, Y., and Ayuela, A. (2005) "Effects of nanosilica additions on cement pastes; Applications of Nanotechnology in Concrete Design, Thomas Telford; London.

Rubenstein, M. (2012) "Emissions from the Cement Industry", Earth Institute, Columbia University, May 9, 2012, https://blogs.ei.columbia.edu/2012/05/09/emissions-from-the-cement-industry.

Scrivener, K.L. (2009) "Nanotechnology and Cementitious Materials" in Z. Bittnar, P.J.M. Bartos, J. Nemecek, V. Smilauer, and J. Zeman, Editors. Nanotechnology in construction: Proceedings of the NICOM3 (3rd International Symposium on Nanotechnology in Construction): Prague, Czech Republic, 2009. p. 37-42.

Seiler, P. H., Eagon, C., Ong, F. S., Farrington, S. A. and Bui, V. (2017) "A New Generation of Micro-Particulate-Based Admixtures for Concrete", ACI Special Publication, Volume 320, pp. 22.1-22.16. 
Sobolev, K., Sanchez F., and Flores I. (2012) "The Use of Nanoparticle Admixtures to Improve the Performance of Concrete", Proceedings of 12th International Conference on Recent Advances in Concrete Technology and Sustainability Issues, pp. 455-469. 